\title{
Who Will Make the Decisions?
}

\author{
Joseph Cosand
}

Over the past several years I have become increasingly concerned about the future of the community colleges and their commitment to the "Open Door Philosophy," "Student Centered Philosophy," "Teaching and Learning Philosophy," and "Community Based Philosophy." These have been the foundations upon which the community colleges have built their educational programs through the belief, dedication and cooperation of the faculty, the administration, the local board, and the community served by the college. For the most part the educational decisions have been made within this group with the underlying support of the state legislature and the governor. The colleges were given the autonomy to provide a diverse educational program of quality for the youth and adults of the community to be served. This provided an educational opportunity at minimal or no cost for all the people who were eligible to enroll regardless of their age, race, affluence, sex, or educational background. The community college was indeed a "people's college." Will this philosophy and service continue?

We read in the Los Angeles Times that "Local Control of Classes Falls Under State Budget Ax," and that "In the Los Angeles Community College District, 118 classes will be dropped, affecting 7,000 students and 91 instructors." In the Association of Community College Trustees' Publication, President Robert N. Rue of C. S. Mott Community College in Flint, Michigan, states that "last January the college turned away 5,000 students, one-half again our total enrollment." The remainder of this essay could be devoted to examples of concern from community colleges throughout the United States. However, the two examples are illustrative of the seriousness of the problems facing the community colleges' educational programs. Of primary concern for this great American educational institution is the decision-making process. Who should make the decisions which will determine the future of the community colleges? 
The decision-making process is complex and the decision makers are numerous, influential and increasingly involved in economic, political, and social pressures which may, can, and perhaps will change the basic community centered philosophy of the community college.

It is essential that we are and remain constantly aware of just who the decision makers are that affect the educational program. It is just as essential that those most affected-the faculty, administration, the local board, the community, and most of all the students served, understand fully the implications of external economic, political, and social pressures on the basic community college philosophies and objectives. An understanding of the implications can result in cooperative and aggressive actions which would preserve the integrity of the community college as a people's college.

Who are the decision makers? They fall into several groups:

1. The Institution-
A. The Board.
B. The president.
C. The other administrators.
D. The faculty-individuals and groups.
E. The support staff.
F. The students.

2. The Community-

A. Advisory Committees.

B. Business, industry, labor, professions

C. Taxpayers.

D. Media.

E. Local government.

F. Pressure groups-organizations.

G. Key individuals.

3. The State
A. State Board of Community Colleges.
B. Chancellors of Community Colleges.
C. State Board or Commission of Higher Education.
D. Chancellors of Higher Education.
E. Legislature.
F. Governor.
G. Budget Director.
H. Taxpayers.
I. Educational Associations.
J. Pressure groups-Organizations.
$\mathrm{K}$. Key individuals.

4. The Federal Government and Washington, D. C.-

A. The Administration.

(1) The White House.

(2) Department of Education.

(3) Other Cabinet Offices.

B. Congress and Congressional Committees. 
C. Congressional Aides.

D. National Higher Education Associations

(1) AACJC, ACCT, AVA, COPA, AGB, ACE, NASFA, etc.

E. Other Associations.

(1) NEA, AFT, AAVP, etc.

F. Pressure Groups.

G. Key individuals, internal and external to government.

As one considers the list it is important to be aware of the following:

1. Who educates whom?

2. Who should be educated about community colleges?

3. Who pressures whom?

4. Who should be pressured about community colleges?

5. Who is affected by pressure?

6. Who is making decisions which affect the philosophy and educational program of the community college?

7. Who should be and is not making or influencing the philosophical, educational and economic decisions affecting the present and the future as related to the community colleges?

The basic concerns to be faced, for the present and the future, are:

1. Education for whom?

2. Education for what purpose?

3. Education at which institution?

4. Education by which faculty?

5. Education with what standards?

6. Education at what cost to whom?

7. Educational decisions by whom?

\section{Education for Whom?}

Are the institutional decision makers committed to the generally accepted philosophy that a person is admissable who is a high school graduate or who is eighteen years of age or older and who can profit from instruction? Are the colleges in advocating this philosophy vulnerable to the accusation that they are attempting to be all things to all people regardless of student abilities or costs to the local and state taxpayers? Have the rapid enrollment increases in community colleges locally, statewide, and nationally at greatly increased costs, which are in competition with other educational and social costs, caused the accepted philosophy to be suspect? If there is questioning of this philosophy by the institutional decision makers it would follow that they would be unable to withstand the attacks now being waged by decision makers at the state and federal levels.

If the philosophy is to be changed with respect to enrollment eligibility, what are the priorities? Will community colleges become selective as to educational background such as a high school diploma or equivalent, or perhaps even a "C" or better average in high school? 
Will the community colleges place a premium on age and set a limit beyond which a person is not eligible to enroll? Will a person with a college degree be declared ineligible since she or he has already enjoyed a college experience? These questions are extremes but we have all heard them verbalized by cost conscious individuals.

Another enrollment problem is being emphasized increasingly by governments and by the media. What standards should a college require for a student to remain in the educational program? Are the colleges too patient with those students who are underprepared and must be given time to make up deficiencies in subject areas and learning skills? Some would say that such students should never have been admitted in the first place.

The institutional decision-makers must know what they believe with respect to enrollment and retention and be prepared through commitment and aggressive action to educate and to exert pressure on the state and federal decision makers, and on the local groups who are still ignorant or emotionally opposed to the philosophy of the comprehensive community college. It continues to be a fact that this uniquely American institution is not understood or properly respected nationally, and in far too many states and local communities. Such lack of understanding creates damaging and simplistic solutions to community college problems by external forces.

\section{Education for What Purpose?}

The comprehensive community college provides a diversity of educational offerings unmatched by other higher education institutions although state colleges and many liberal arts colleges are increasingly emulating such diversity. Is there too much diversity for one institutional type? Is there too much duplication of programs among the various types of institutions? Are states correct in attempting to curtail duplication or in eliminating certain parts of the community college comprehensive program? Should there be state master plans to specify exactly what the educational programs of each type of higher education institution should be?

Specifically a community college with a broad diverse educational program will offer:

1. Academic preparation through the lower division.

2. General education for all students for breadth of understanding, appreciation and enjoyment.

3. Vocational education.

4. Technical and para-professional education.

5. Remedial education from early elementary on.

6. Continuing education-broad.

7. Community services-broad.

8. Career counseling, and placement centers.

9. Child care or child development centers.

10. Classes throughout the community-day or evening-seven days a week. 
The list could be broke down into many subitems which, when viewed in their entirety, are quite awesome. They are descriptive of the evolution and growth of the academic-vocational junior college into the present comprehensive institution. Is it too much for one institution? As has been suggested, should the public four-year colleges take over the academic transfer program, especially since the community colleges are becoming more and more oriented toward technical education and adult education? The institutional decisionmakers must be in agreement concerning the purposes of their colleges. They must again educate and pressure aggressively the external decision-makers. The integrity of the college as well as the type of institution demands that the purpose advocacy is defensive as to both need and the ability to provide quality in every aspect of the educational program.

\section{Education at Which Institution?}

It is high time for community colleges, universities, state colleges, technical institutes and area vocational schools to work together to serve best the local, state, and national constituencies. Most educational decisions should rest with the institution decision makers. This could be the case if there were cooperative understandings and actions. The absence of cooperation results in external decisions by state and federal governments through legislation and administrative action. Legislatures, budget directors, state boards and state chancellors will increasingly influence the philosophy and educational programs of community colleges and of all higher education if the institutional decision makers fail in their responsibility to make defensible and credible decisions.

\section{Education By Which Faculty?}

Today's faculty are much different from those who taught in the earlier junior colleges. Most then were employed from the ranks of high school teachers; they were probably less academic and more student oriented. There were also far fewer part-time faculty. Increasingly full-time faculty members come from a four-year college teaching position, from a university where they were preparing to teach in a four-year college, or from the business, industrial or professional areas. Of perhaps more significance is the rapid increase in the number and percentage of part-time teachers recruited from the local communities. These two changes raise two questions, especially for the institutional decision makers:

1. Are the faculty from the four-year colleges and from university preparation equipped for the community college diversity of students? If not, what in-service education is provided?

2. Is there a "critical mass" of full-time faculty needed to provide leadership and stability within the college? Are the savings in costs, the flexibility in assignments, and the expertise of the part-time teacher creating a possible tidal wave which could endanger the overall continuous development of the college? 


\section{Education With What Standards?}

This appears to be a growing concern in the media, in state boards, and in the state and federal governments. The institutional decisionmakers are mandated to maintain quality in all of the colleges' offerings. This would include all ten of the educational programs listed previously under the purpose of the community college. Any deviation from adherence to quality will destroy the image of the community college by type, as well as by institution. Transfer students should be competitive at the receiving institution. Vocational and technical students should be well-prepared for employment. Remedial students should be required to progress in a satisfactory manner for retention in the college. Continuing education and community service programs should be defensible to the community served; if not, they should be self-supporting.

\section{Education at What Cost to Whom?}

A major factor in the growth and development of the community college has been low cost to the student. In many respects, as in California, it has continued no cost or low cost education through the 14th grade. As complexity of the educational programs has increased, so have the enrollments and the costs to both the students and the taxpayers. The Los Angeles and Mott Community College, cited earlier, are examples of curtailment of government and taxpayer support. Increased tuition costs for students along with decreased student financial aid will exacerbate the problem. The institutional, state, and federal decision-makers are faced with a joint decision. This cannot be a unilateral decision on the part of any one segment. There must be an education of all as to program, costs, and revenue. There must be an understanding as to other demands upon the local, state, and national taxpayers and budgets. There must be an understanding within higher education, both public and private, as to total mission and mission by type of institution. Higher education as a whole and the community colleges in particular are too essential to the continued development of this country and of the world, to leave the decision making to those locally, state, or nationally who are ignorant, unaware, apathetic or biased about the great value of education in the future of our civilization. The undereducated decision makers must be educated factually, realistically, and philosophically.

Joseph Cosand is Professor Emeritus of Higher Education, The University of Michigan, Center for the Study of Higher Education, Ann Arbor, Michigan. 